\title{
PENERAPAN LAYANAN KOMPUTASI AWAN UNTUK SISTEM MANAJEMEN PENGETAHUAN PADA INSTITUSI PENDIDIKAN TINGGI
}

\author{
Nanang Kurnia Wahab \\ Program Studi Manajemen Informatika, AMIK Tri Dharma Pekanbaru \\ Jalan Jenderal Sudirman No.68 (Pelita Pantai) Pekanbaru \\ E-Mail :nanang@amiktridharma.ac.id
}

\begin{abstract}
ABSTRAK
Komputasi Awan (Cloud Computing) menjadi sebuah teknologi yang memiliki sumberdaya komputasi powerfull dapat diterapkan bagi banyak organisasi dengan penggunaan skalabilitas dinamis sebagai sumber layanan virtual melalui internet. Dengan memanfaatkan layanan aplikasi berbasis cloud yang ditawarkan oleh penyedia memungkinkan bagi pengguna untuk melakukan proses bisnis ataupun layanan sistem informasi berupa aplikasi yang dapat diakses di mana saja, kapan saja oleh pemangku kepentingan institusi pendidikan tinggi. Penerapan Sistem Manajemen Pengetahuan (Knowledge Management System) merupakan salah satu sistem informasi strategis yang dapat meningkatkan daya saing (competitive advantages) bagi institusi pendidikan tinggi. Penggunaan layanan cloud computing dapat meningkatkan efisiensi biaya dan proses pengelolaan infrastruktur TI sesuai standar strategi implementasi TI institusi pendidikan tinggi.
\end{abstract}

Kata Kunci : Komputasi Awan, Sistem Manajemen Pengetahuan, Institusi Pendidikan Tinggi.

\section{ABSTRACT}

Cloud Computing technology has become a powerful computing resources can be applied to many organizations with the use of dynamic scalability as the source virtual services over the internet. By utilizing cloud-based application services offered by providers allow for users to perform business process or service information system in the form of applications that can be accessed anywhere, anytime by stakeholders of higher education institutions. Application of Knowledge Management Systems is one of the strategic information systems that can improve competitive advantages for higher education institutions. The use of cloud services improve cost efficiency and process management of the IT infrastructure according to the standard IT implementation strategies of higher education institutions.

Keywords : Cloud Computing, Knowledge Management Systems, Higher Education Institutions

\section{PENDAHULUAN}

Cloud computing menjadi sebuah teknologi yang memiliki sumberdaya komputasi powerfull dapat diterapkan bagi banyak organisasi dengan penggunaan skalabilitas dinamis sebagai sumber layanan virtual melalui internet. Teknologi ini akan memiliki dampak yang signifikan pada lingkungan pendidikan dan dapat menjadi alternatif bagi lembaga pendidikan yang memiliki anggaran terbatas dapat meningkatkan efisiensi penghematan biaya dalam mengoperasikan sistem informasi secara efektif tanpa mengeluarkan modal lebih untuk menyediakan banyak komputer dan perangkat jaringan (Ercan, 2010).

\section{Menurut National Institute of} Standards and Technology (NIST) komputasi awan (cloud computing) adalah sebuah bentuk layanan yang membuka peluang untuk dapat hadir dimanapun, memberikan kenyamanan, akses jaringan sesuai permintaan (on-demand) ke lokasi sumber daya komputasi terkonfigurasi (misalnya, jaringan, server, penyimpanan, aplikasi dan layanan), yang dapat dengan cepat dijalankan dan diluncurkan, dengan upaya pengelolaan minimal atau dengan 
menggunakan penyedia jasa layanan (Mell dan Grance, 2011).

Pada saat ini ketatnya persaingan institusi pendidikan tinggi menuntut perlu dibentuk suatu strategi keunggulan bersaing dengan memanfaatkan infrastruktur TI. Penerapan Sistem Manajemen Pengetahuan (Knowledge Management System) merupakan salah satu sistem informasi strategis yang dapat meningkatkan daya saing (competitive advantages) bagi institusi pendidikan tinggi dan dapat dibangun dengan menggunakan layanan teknologi informasi berbasis cloud computing (Solichin dan Hasibuan, 2012).

Dengan adanya penerapan layanan cloud computing untuk knowledge management system proses penciptaan, kolaborasi, komunikasi dan dokumentasi pengetahuan memungkinkan dapat diakses dari manapun dan kapanpun oleh seluruh pemangku kepentingan (stakeholder) sehingga dapat meningkatkan saya saing (competitive advantage) bagi institusi pendidikan tinggi tersebut.

\section{Rumusan Masalah}

Berdasarkan permasalahan yang ada pada latar belakang masalah yang diteliti dirumuskan dalam bentuk perumusan masalah adalah bagaimana menerapkan teknologi cloud computing dapat digunakan sebagai sebuah layanan knowledge management system untuk menciptakan keunggulan kompetitif bagi institusi pendidikan tinggi?

\section{Batasan Masalah}

Pada pembahasan penelitian ini batasan masalah difokuskan sebagai berikut : a. Ruang lingkup penelitian dilakukan hanya pada institusi pendidikan tinggi AMIK "Tri Dharma" Pekanbaru.

b. Jenis model layanan cloud computing yang digunakan pada institusi pendidikan tinggi adalah berbasis Software as Service (SaaS).

c. Perancangan Knowledge Management System pada institusi pendidikan tinggi menggunakan acuan Framework "The 10-step Knowledge Management Roadmap" oleh Amrit Tiwana.

d. Pengelolaan Knowledge Management System dirancang menggunakan prototype web portal menggunakan aplikasi eXo platform.

\section{Tujuan}

Dalam penelitian ini, terdapat beberapa tujuan yang ingin dicapai, yaitu:

a. Mengetahui hubungan antara layanan Cloud Computing dan Knowledge Management System yang diimplementasikan pada institusi pendidikan tinggi.

b. Membangun prototype web portal Knowledge Management System menggunakan aplikasi eXo Platform.

c. Menguji apakah layanan Cloud Computing dapat diimplementasikan pada Knowledge Management System untuk institusi pendidikan tinggi.

\section{Manfaat}

Manfaat dari penelitian ini yaitu memahami jenis layanan Cloud Computing dan manfaatnya untuk diterapkan sebagai model Knowledge Management System pada lembaga pendidikan tinggi.

\section{Komputasi Awan (Cloud Computing)}


Komputasi awan (cloud computing; cloud) adalah sebuah bentuk layanan yang membuka peluang untuk dapat hadir dimanapun, memberikan kenyamanan, akses jaringan sesuai permintaan (ondemand) ke lokasi sumber daya komputasi terkonfigurasi (misalnya, jaringan, server, penyimpanan, aplikasi, dan layanan), yang dapat dengan cepat dijalankan dan diluncurkan, dengan upaya pengelolaan minimal atau dengan menggunakan penyedia jasa layanan (Mell dan Grance, 2011).

Bentuk karakteristik utama dari cloud computing menurut NIST (Mell dan Grance, 2011) sebagai berikut :

a. Swalayan (On-demand self-service)

b. Akses pita lebar (Broad network access)

c. Sumber daya terkelompok (Resource pooling)

d. Elastis (Rapid elasticity)

e. Layanan yang terukur (Measured service)

Model layanan cloud computing dijelaskan oleh NIST (Mell dan Grance, 2011) sebagai berikut :

a. Software as a Service (SaaS)

b. Platform as a service (PaaS)

c. Infrastructure as a service (IaaS)

Bentuk penyebaran cloud computing dijelaskan oleh NIST (Mell dan Grance, 2011) sebagai berikut :
a. Private Cloud
b. Community Cloud
c. Public Cloud
d. Hybrid Cloud

\section{Knowledge Management}

Menurut Turban (2008) Knowledge (pengetahuan) adalah informasi yang kontekstual, relevan dan "actionable", alat pragmatis untuk memanipulasi dan mengontrol dunia, bersifat komunal, aktivitas spesifik, terdistribusi dan historis-cultural (Subagdja, 2011).

Umumnya, para pakar membagi knowledge ke dalam 2 jenis, yaitu :

a. Tacit Knowledge, yaitu pengetahuan yang bersifat subyektif, kognitif dan pembelajaran yang berasal dari pengalaman (Nonaka dan Takeuchi, 1995), sebagai pengetahuan yang tertanam (embedded knowledge), yang relatif sulit untuk dikeluarkan dari sumbernya (sticky knowledge).

b. Explicit Knowledge, yaitu pengetahuan yang bersifat objektif, rasional dan teknis. Disebut juga sebagai leaky knowledge karena sifatnya yang mudah untuk ditinggalkan dari seseorang, dokumen atau organisasi setelah semuanya didokumentasikan.

Untuk proses penciptaan pengetahuan atau konversi pengetahuan terdapat empat mode yang dikenal dengan model SECI (Suzianti et al., 2014), yaitu :

\section{a. Proses Socialization}

Merupakan proses yang paling dasar dalam melakukan penyebarluasan suatu pengetahuan. Pada proses socialization terjadi interaksi sosial antar individu sehingga terjadi interaksi antar pengetahuan tacit, umumnya bentuk proses socialization adalah diskusi, cerita, ataupun sharing (berbagi) pengalaman.

b. Proses Externalization

Merupakan proses pengubahan/ penerjemahan pengetahuan dalam bentuk tacit menjadi pengetahuan yang eksplisit (nyata), umumnya dalam bentuk tulisan ataupun gambar. Proses externalization tersebut dapat membantu 
pengubahan pengetahuan tacit seseorang ke dalam bentuk pengetahuan eksplisit yang dapat dipahami dengan mudah oleh orang lain.

c. Proses Combination

Merupakan proses terjadinya penyebarluasan dan/atau pengembangan dari pengetahuan-pengetahuan eksplisit yang telah ada. Pengetahuan yang telah terdokumentasikan dapat disebarluaskan melalui suatu pertemuan dalam bentuk dokumen ataupun melalui suatu proses pendidikan atau pelatihan.

d. Proses Internalization

Merupakan proses terjadi perubahan pengetahuan eksplisit menjadi pengetahuan tacit, umumnya dilakukan melalui proses belajar dan/atau penelitian yang dilakukan ataupun pengalaman yang dilalui oleh setiap individu.

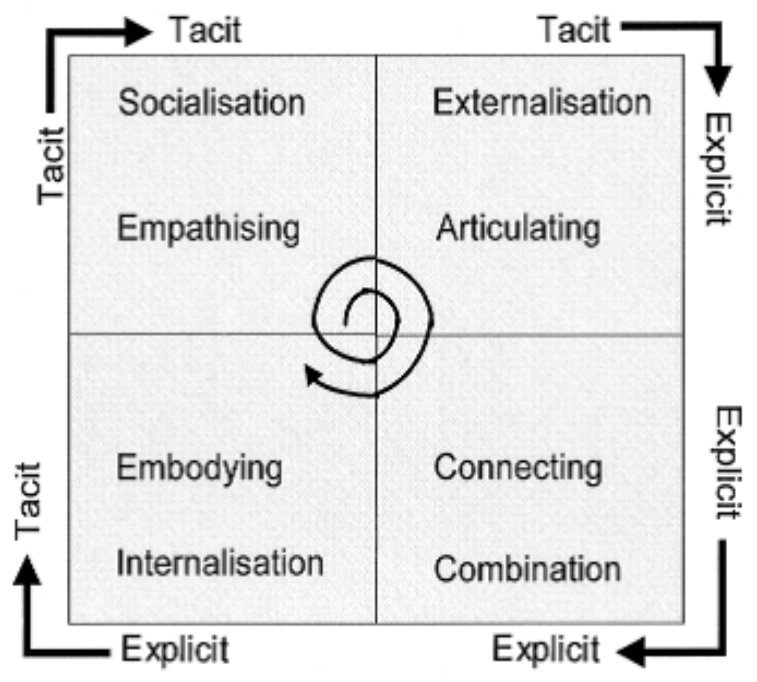

Gambar 2. Proses Konversi Tacit Knowledge dan Explicit Knowledge

\section{Knowledge Management System}

Knowledge management dilaksanakan dalam sistem manajemen pengetahuan (Knowledge Management System). Menurut
Dilip Bhatt (2000) Dalam menerapkan $K M S$, memiliki komponen yang saling terkait satu sama lain, yaitu Manusia (People), Proses (Process), dan Teknologi (Technology) (Retnoningsih, 2013)

Untuk merancang dan menerapkan knowledge management system, menurut Tiwana (2002) ada sepuluh tahap langkah strategis yang bisa dilakukan oleh organisasi. Sepuluh tahap langkah tersebut dikenal dengan istilah "The 10-step knowledge management roadmap". Setiap tahap langkah tersebut dibagi dalam 4 fase (Sari dan Tania, 2014), yaitu:

A. Fase Evaluasi Infrastruktur

1. Menganalisa infrastruktur yang telah ada

2. Menyelaraskan KM dan Strategi Bisnis

B. Fase Analisis, Perancangan dan Pembangunan KM System

3. Merancang Infrastruktur KM

4. Mengaudit aset pengetahuan dan sistem yang ada

5. Merancang tim KM

6. Membuat cetak biru (Blueprint) KM

7. Membangun KMS

C. Fase Deployment

8. Menjalankan KMS (deployment) menggunakan Result-driven Incremental Methodology.

9. Mengelola perubahan, budaya dan struktur penghargaan.

D. Fase Evaluasi

10. Mengevaluasi kinerja, mengukur ROI, dan memperbaiki KMS secara bertahap.

\section{METODE}

\section{Analisis Kebutuhan Sistem}

Berdasarkan hasil evaluasi dengan melihat masalah dan sistem kerja yang ada 
terutama dalam sistem membangun portal $K M S$, solusi yang akan diberikan adalah menyediakan layanan $K M S$ dengan konsep cloud computing. Selain itu cloud computing yang akan dikembangkan yaitu sebagai layanan Software as a Service (SaaS) akan memberikan banyak keuntungan bagi institusi pendidikan tinggi.

Dalam pengembangan aplikasi cloud computing ini dilakukan pemilihan komponen-komponen yang akan digunakan untuk implementasi Portal KMS yang di"tanamkan" pada sistem cloud. Komponenkomponen tersebut dapat dilihat pada gambar dibawah ini.

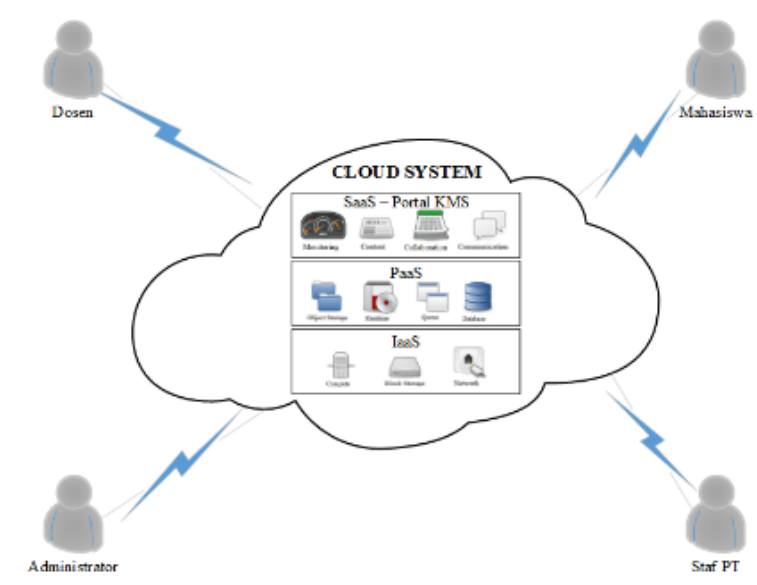

Gambar 3. Usulan Pengembangan Model Cloud System

Dari gambar 3 diatas merupakan gambaran umum dari pengembangan model sistem yang dikembangkan dan di"tanam" dalam system cloud. Gambar diatas menjelaskan bahwa aplikasi Portal KMS dapat diakses oleh banyak pengguna, tersedianya infrastruktur dan data tersimpan secara terpusat yaitu di "cloud". Sehingga pengguna tidak perlu tahu bagaimana dan darimana sumber daya komputasinya dipenuhi oleh penyedia layanan (cloud service provider), karena dapat digunakan bersama-sama oleh sejumlah pengguna (user).

\section{Analisa Knowledge Management System Pada Institusi Pendidikan Tinggi}

AMIK Tri Dharma sebagai institusi pendidikan tinggi menggunakan mediamedia berikut ini sebagai sarana komunikasi antar sumber daya manusia yang ada di lingkungan kampus dan pihakpihak yang berkepentingan (stakeholder), yaitu sebagai berikut :

1. Forum Diskusi, saat ini sedang berjalan pada AMIK Tri Dharma adalah dengan cara melakukan pertemuan di kelas antara Dosen dengan Mahasiswa atau rapat secara langsung (tatap muka) antara Dosen dengan Dosen atau Dosen dengan Staf Karyawan.

2. Penyimpanan Serta Penyebaran (Sharing) Materi Ajar, saat ini materi ajar masih dimiliki oleh masing-masing dosen dan penyimpanan serta penyebaran (sharing) materi ajar tidak tersimpan dalam satu sistem.

3. Pengumuman dan Agenda Kegiatan Akademik pada AMIK Tri Dharma saat ini masih manual, yaitu melakukan pemberitahuan melalui papan pengumuman yang disebarkan dari mulut ke mulut. Tentunya hal ini tidak adanya fleksibilitas waktu dan tempat.

Dengan adanya pengelolaan Portal $K M S$ yang tepat guna merupakan perwujudan dari model SECI Nonaka \& Takeuchi, digunakan perangkat teknologi informasi yang ada di AMIK Tri Dharma Pekanbaru, sebagai berikut :

1. Sosialisasi

Proses sosialisasi antar Sumber Daya Manusia (SDM) di AMIK Tri Dharma Pekanbaru salah satunya dilakukan 
melalui pertemuan tatap muka. Melalui pertemuan tatap muka ini, SDM AMIK Tri Dharma Pekanbaru dapat saling berbagi knowledge dan pengalaman yang dimilikinya, sehingga tercipta knowledge baru bagi mereka.

2. Eksternalisasi

KMS akan sangat membantu proses eksternalisasi ini, yaitu proses untuk mengartikulasi tacit knowledge menjadi suatu konsep yang jelas.

3. Kombinasi

Proses konversi knowledge melalui kombinasi yaitu mengkombinasikan berbagai explicit knowledge yang berbeda untuk disusun ke dalam $K M S$.

\section{Internalisasi}

Semua dokumen data, informasi dan knowledge yang sudah didokumentasikan dapat dibaca oleh orang lain. Pada proses inilah terjadi peningkatan knowledge SDM. Sumbersumber explicit knowledge dapat diperoleh melalui media intranet (database organisasi), Surat Edaran/Surat Keputusan, papan pengumuman dan internet serta media massa sebagai sumber eksternal.

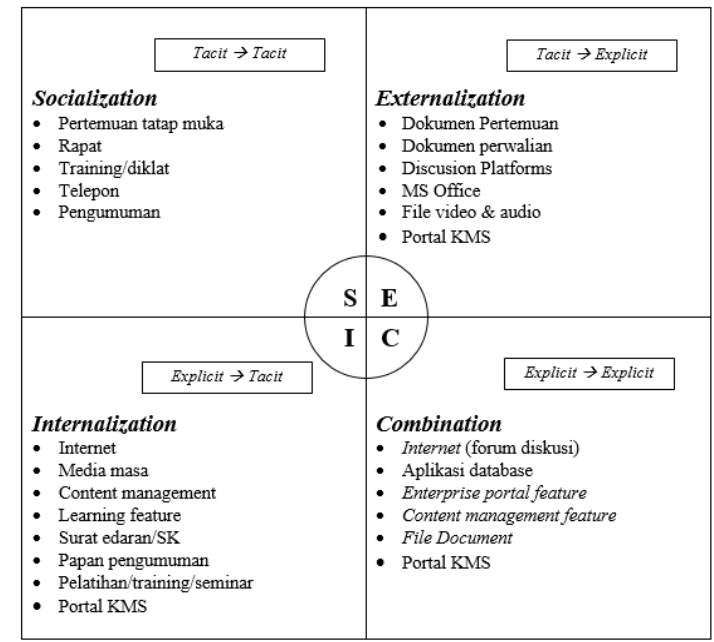

Gambar 4. Pemetaan Infrastruktur Teknologi Informasi ke dalam Proses SECI
Gambar 4. merupakan perwujudan dari siklus knowledge yang dipetakan menggunakan model SECI Nonaka \& Takeuchi. Untuk dapat menerapkan $K M$ ini, tidak hanya didukung oleh SDM yang berkualitas (memiliki informasi, pengalaman dan keahlian yang dibutuhkan) dan teknologi informasi yang tepat guna, tetapi juga budaya dalam berbagi pengetahuan (knowledge sharing).

\section{HASIL}

\section{Perancangan Model Knowledge Management System}

Tahapan dalam pengembangan Knowledge Management System yang akan diimplementasikan menggunakan layanan cloud computing dapat bagi dalam beberapa fase, yaitu :

\section{a. Fase Evaluasi Infrastruktur}

Berdasarkan hasil penelitian infrastruktur yang terdapat pada AMIK Tri Dharma Pekanbaru, telah terdapat beberapa infrastruktur seperti di bawah ini:

1. Koneksi Intranet/Local Area Network (LAN), telah menggunakan kabel, kabel UTP cat6, Lan Card 1Gbps dan Switch hub.

2. Koneksi Internet, dengan menggunakan 2 provider, yaitu Telkomspeedy dan Indosat M2.

3. Bandwith untuk internet 4 Mbps (1 Mbps dari Telkom Speedy, 3 Mbps dari Indosat M2), sedangkan untuk LAN, bandwidth bisa mencapai $1 \mathrm{Gbps}$.

4. Sistem Konfigurasi LAN/WAN, menggunakan Mikrotik Router untuk mengatur bandwidth dan DHCP server untuk menentukan IP address otomatis. 


\section{b. Analisis, Perancangan dan Pembangunan Knowledge Management System}

Untuk merancang Portal KMS yang dapat membantu pihak institusi pendidikan tinggi untuk meningkatkan kinerjanya diperlukan empat komponen, yaitu sebagai berikut.

1. Manusia (people), institusi pendidikan tinggi menunjuk/memperkerjakan seorang Administrator atau Knowledge Manager yang bertanggung jawab mengelola KMS dengan cara mendorong para Dosen, Staf Karyawan Perguruan Tinggi (PT) dan Mahasiswa untuk mendokumentasikan dan mempublikasikan knowledge mereka, mengatur file dan menghapus knowledge yang sudah tidak relevan.

2. Proses, perancangan serangkaian proses yang mengaplikasikan konsep model SECI dalam pelaksanaannya.

3. Teknologi, dibuat usulan infrastruktur TI yang diperlukan untuk menunjang berjalannya KMS yang efektif. Infrastruktur TI yang telah dirancang sebelumnya yaitu menggunakan konsep cloud computing, diimplementasikan dan digunakan dengan sehingga proses penyebaran infromasi dan komunikasi menggunakan portal KMS oleh user dapat dilakukan dimana dan kapan saja.

4. Content (isi), dirancang content dari KMS yaitu berupa database knowledge dan dokumen yang dibutuhkan oleh Dosen, Staf Karyawan dan Mahasiswa untuk melakukan sharing knowledge melalui Portal KMS, dengan isi content bisa berupa modul pembelajaran, surat edaran, surat keputusan, pengumuman, pelatihan, training, seminar dan informasi lainnya.

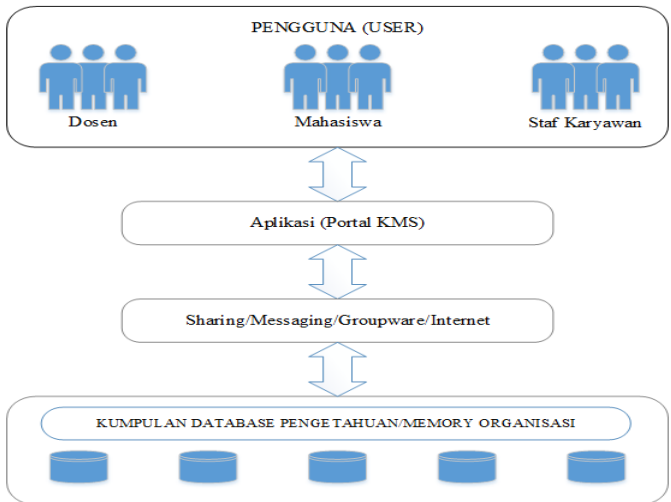

Gambar 5. Arsitektur Bisnis Knowledge Management System

Sesuai Gambar 5 arsitektur bisnis KMS yang dibangun terdiri dari beberapa layer sebagai berikut :

1. Layer pertama adalah user yang dalam hal ini adalah knowledge worker yaitu Dosen, Mahasiswa, Staf Karyawan dan stakeholder lainnya.

2. Layer kedua adalah user interface berupa browser internet ataupun aplikasi lainnya.

3. Layer ketiga adalah communication/transport layer yang dalam hal ini berupa sharing, groupware dan internet.

4. Layer keempat adalah kumpulan

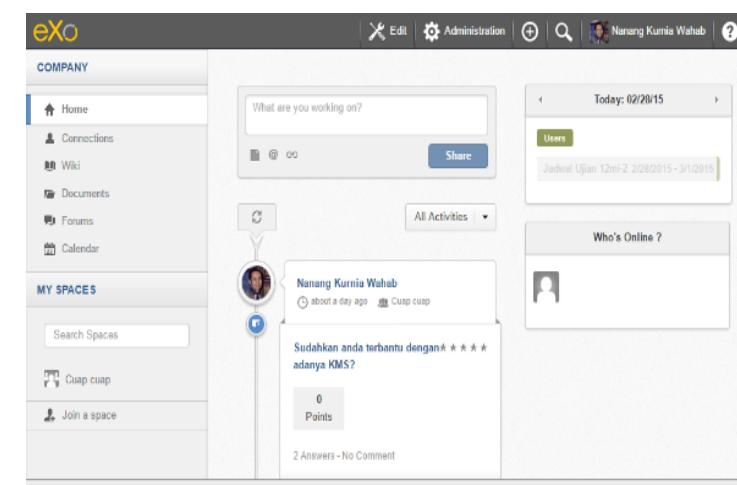

database-database pengetahuan KMS. 


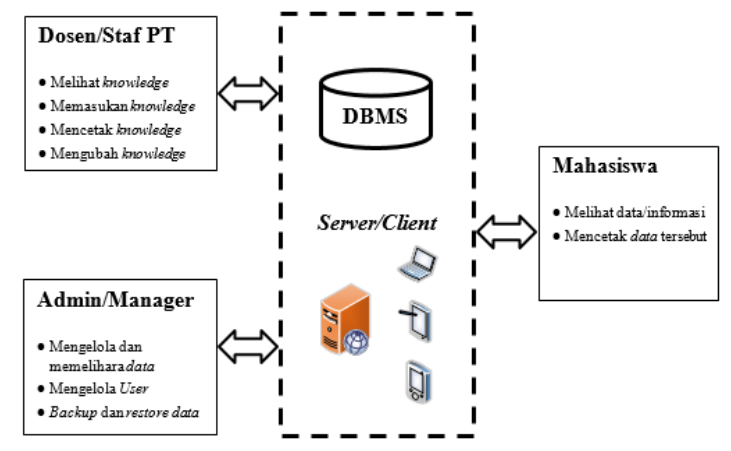

Gambar 6. Diagram Blok Portal KMS yang Dikembangkan

Pada Gambar 6 dijelaskan diagram blok portal KMS tugas dari masing-masing elemen sistem serta peran masing-masing stakeholder, sebagai berikut :

1. Dosen/Staf Karyawan Perguruan Tinggi
a) Melihat knowledge
b) Memasukan knowledge
c) Mencetak knowledge
d) Mengubah knowledge

2. Administrator/Manager KMS

a) Mengelola dan memelihara data

b) Mengelola User

c) Backup dan restore data

3. Mahasiswa

a) Melihat data/informasi

b) Mencetak data tersebut

\section{c. Fase Pengembangan}

Pada pengembangan Portal KMS menggunakan layanan cloud computing memanfaatkan jenis model layanan Software as a Service (SaaS) dalam membangun sebuah aplikasi semua data akan tersimpan pada cloud (awan). Untuk dapat dikatakan sebagai layanan Software as a Service (SaaS) maka perangkat lunak harus memenuhi beberapa karakteristik, yaitu :

1. Berbasis internet, perangkat lunak yang dibangun akan dapat diakses dan dikelola oleh pengguna melalui internet.
2. Perangkat lunak yang dibangun bersifat terpusat, sehingga pengguna dapat mengaksesnya darimana saja dan kapan saja.

3. Aplikasi yang dikembangkan untuk portal KMS bersifat multiuser.

Untuk pengembangan portal KMS agar dapat diimplementasikan dengan baik untuk menjalankan sistem maka diputuskan untuk menggunakan software eXo Platform yang merupakan aplikasi open source platform jejaring sosial yang dapat digunakan untuk alat kolaborasi antar pengguna dengan antarmuka "social" yang sangat mudah digunakan. Dengan eXo Platform, dapat mengomentari posting, upload dan berbagi dokumen, membuat kelompok, dan masih banyak lagi.

\section{d. Fase Evaluasi Performance KMS}

Pada tahapan ini hasil dari implementasi $K M S$ sudah mulai diukur dan dievaluasi. Dalam melakukan pengukuran dan evaluasi dapat dilakukan dengan menguji apakah aplikasi Portal KMS telah dibangun telah memenuhi kebutuhan dari user yang menggunakannya.

\section{Implementasi Layanan Cloud Computing}

Untuk dapat mengembangkan dan menjalankan layanan portal KMS menggunakan Google Cloud, konfigurasi sistem yang digunakan sebagaimana gambar 7 . 


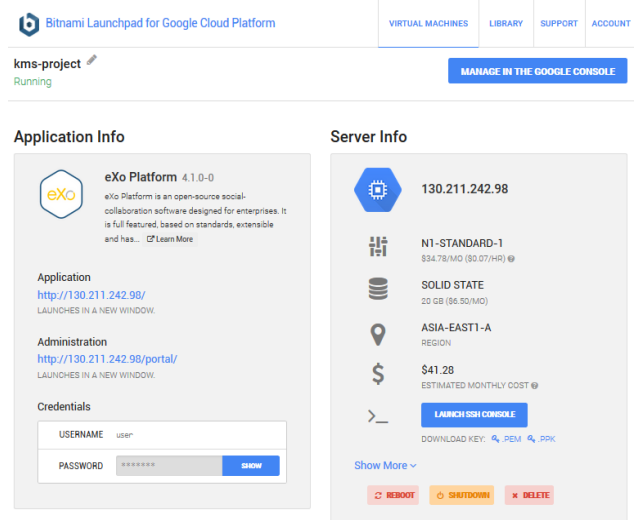

Gambar 7. Informasi Mesin Virtual Portal $K M S$

Tampilan dari halaman depan pengguna (user), di mana tampilan ini berfungsi untuk membagikan informasi dan mengetahui informasi yang diberikan oleh user lainnya.

Gambar 8. Halaman Depan Pengguna (User)

\section{Pengujian Fungsionalitas Sistem}

Berdasarkan hasil pengujian yang dilakukan oleh Peneliti diperoleh data bahwa prototype Portal KMS menggunakan konsep layanan Cloud Computing yang dibangun berjalan sesuai dengan spesifikasi kebutuhan pengguna, hasil uji terinci pada table.

Tabel 1. Hasil Pengujian Kesesuaian Kebutuhan Pengguna (User)

\begin{tabular}{|c|l|c|}
\hline No & \multicolumn{1}{|c|}{ Kebutuhan Pengguna } & Hasil \\
\hline 1. & $\begin{array}{l}\text { Tersedianya layanan cloud computing untuk portal KMS } \\
\text { yang dapat diakses melalui internet? }\end{array}$ & Ya \\
2. & $\begin{array}{l}\text { Apakah Portal KMS dapat diakses melalui internet oleh } \\
\text { multi user di mana saja dan kapan saia? }\end{array}$ & Berhasil \\
3. & $\begin{array}{l}\text { Apakah fitur Portal KMS yang disediakan sudah memenuhi } \\
\text { standar proses penvebaran informasi, penciptaan, kolaborasi. } \\
\text { komunikasi dan dokumentasi pengetahuan (knowledge)? }\end{array}$ & Ya \\
4. & $\begin{array}{l}\text { Efisiensi dalam biaya dan proses pengelolaan infrastruktur } \\
\text { TI sesuai standar strategi implementasi TI? }\end{array}$ & $\mathrm{Ya}$ \\
\hline
\end{tabular}

\section{KESIMPULAN}

Berdasarkan hasil pengujian dapat diambil kesimpulan-kesimpulan, yaitu :
1. Knowledge Management System (KMS) telah berhasil diterapkan menggunakan aplikasi cloud computing, dari hasil ini dapat disimpulkan bahwa penerapan Knowledge Management System pada institusi pendidikan tinggi AMIK Tri Dharma Pekanbaru dengan menggunakan aplikasi cloud computing telah berjalan dengan baik.

2. Portal Knowledge Management System yang dibangun menggunakan aplikasi aXo Platform dapat mengintegrasikan sistem manajemen pengetahuan yang dikembangkan pada AMIK Tri Dharma Pekanbaru.

3. Knowledge Management System merupakan salah satu sistem yang diperlukan dalam proses penyebaran informasi dan pengetahuan dalam kegiatan belajar mengajar pada institusi pendidikan tinggi AMIK Tri Dharma Pekanbaru, selain sistem KMS masih terdapat sistem lain yang diperlukan untuk melengkapi proses bisnis institusi tersebut. Saran dari kondisi ini adalah membangun sistem lainnya sehingga mendukung seluruh proses kegiatan bisnis institusi yang sedang berjalan.

\section{DAFTAR PUSTAKA}

[1]. Ercan. 2010. Effective use of cloud computing in educational institutions. Procedia - Social and Behavioral Sciences. Vol 2, 938942.

[2]. Mell, Grance. 2011. The NIST Definition of Cloud Computing Recommendations of the National Institute of Standards and 
Technology. NIST Special Publication 800-145.

[3]. Nonaka, Takeuchi. 1995. The Knowledge-Creating Company : How Japanese Companies Create the Dynamics of Innovation, Oxford University Press.

[4]. Nugroho, Mustofa. 2012. Implementasi Komputasi Awan Menggunakan Teknologi Google App Engine (GAE) dan Amazon $W e b \quad$ Services (AWS). Jurnal Informatika. Vol 6, Nomor 1.

[5]. Retnoningsih. 2013. Knowledge Management System (KMS) Dalam Meningkatkan Inovasi LPPM Perguruan Tinggi. Jurnal Evolusi. Vol.I No.1.

[6]. Sari, Tania. 2014. Penerapan Knowledge Management System (KMS) Berbasis Web Studi Kasus Bagian Teknisi dan Jaringan Fakultas Ilmu Komputer Universitas Sriwijaya. Jurnal Sistem Informasi (JSI). Volume 6 No.2.

[7]. Solichin, Hasibuan. 2012. Pemodelan Arsitektur Teknologi Informasi Berbasis Cloud Computing untuk Institusi Pendidikan Tinggi di Indonesia. Sematik 2012.

[8]. Subagdja. 2011. Perancangan Knowledge Management System untuk Pelayanan Perizinan Terpadu Satu Pintu. Konfrensi Teknologi Informasi dan Komunikasi untuk Indonesia. eIII2011.

[9]. Sulistyowati, Sulistyo, Indra Bayu. 2012. Implementasi Cloud Computing sebagai Infrastructure as a Service untuk Penyediaan Web
Server. Jurnal Teknologi InformasiAITI. Vol.9 No.2.

[10]. Suzianti, Hanum, Anisah, Aprilliandry. 2014. Knowledge Management System for Creative Small Medium Enterprise in Indonesia - Case study: Batik. International Journal of Sustainable Human Development. Volume 2. 